\begin{tabular}{|c|c|c|}
\hline Beitr. Ent. & Keltern & ISSN 0005-805X \\
\hline $51(2001) 2$ & S. $335-340$ & 16.12 .2001 \\
\hline
\end{tabular}

\title{
A revision of the Palaearctic species of Myrmecopora SAULCY, 1864. IV. A new species from Turkey and additional records
}

\section{(Coleoptera: Staphylinidae, Aleocharinae, Falagriini)}

With 8 figures and 1 map

VOLKER ASSING

\section{Summary}

Myrmecopora (s. str.) ciliciana sp. n. from southern Anatolia, a myrmecophilous species associated with ants of the genus Messor FOREL, is described, figured, and distinguished from similar congeners of $M y r m e c o p o r a$ s. str. Additional records are presented for several species of $M y$ mecopora SAULCY, among them the recently described $M$. (s. str.) wunderlei ASSING, whose known area of distribution is mapped.

Key words

Coleoptera - Staphylinidae - Aleocharinae - Falagriini - Myrmecopora - Palaearctic region - Turkey - taxonomy - new species - new tecords - myrmecophily

\section{Zusammenfassung}

Myrmecopora (s. str.) ciliciana sp. n., eine mytmecophile, bei Ameisen der Gattung Messor FOREL lebende Art, wird beschrieben und von ähnlichen Arten der Untergattung Myrmecopora s. str. unterschieden; Differentialmerkmale werden abgebildet. Bisher unpublizierte Nachweise weiterer Myrmecopora-Arten werden vorgelegt, darunter auch neue Funde der erst kürzlich beschriebenen $M$. (s. str.) wunderlei AssING; die derzeit bekannte Verbreitung dieser Art wird anband einer Karte illustriert.

\section{Introduction}

The falagriine genus Myrmecopora SAULCY was recently revised in three steps and currently includes 25 Palaearctic species in 6 subgenera, the vast majority of them $(21$ species, 5 subgenera) in the Western Palaearctic region (Assing, 1997a, 1997b, 1999). While most species of the genus inhabit coastal habitats, the available data suggest that all the species of the Western Palaearctic subgenus Myrmecopora s. str. are apparently myrmecophiles strictly associated with ants of the genus Messor FOREL. Four species of the subgenus have previously been recorded from Turkey.

During a field trip to southern Anatolia carried out by PAUL WUNDERLE (Mönchengladbach) and myself in December 2000, yet another species of Myrmecopora s. str. was discovered in the area northwest of Tarsus (eastern Mersin), so that the subgenus now includes a total of ten species, five of them occurring in Turkey. Apart from the description of this new taxon, additional records of other species of Myrmecopora are presented below. 
2. Material, measurements, and abbreviations

The material examined is deposited in the following institutions and private collections:

MHNG Muséum d'Histoire Naturelle, Genève (G. CuCCODORO)

MNHUB Museum für Naturkunde der Humboldt-Universität, Berlin (M. UHLIG)

cAss author's private collection

cFel private collection B. FELDMANN, Münster

cMif private collection D. Mifsud, Malta

cSol private collection A. SoLODOnNIKoy, St. Petersburg

cWun private collection P. WUNDERLE, Mönchengladbach

The measurements are given in $\mathrm{mm}$ and abbreviated as follows:

TL: $\quad$ total length from anterior margin of labrum to apex of abdomen

AL: $\quad$ length of antennae

HL: head length from anterior margin of clypeus to neck

HW: $\quad$ maximal head width

PL: $\quad$ length of ptonotum

PW: $\quad$ maximal width of pronotum

EL: length of elytra along suture from apex of scutellum to posterior margin

HTiL: length of metatibia

HTaL: length of metatarsus

HT1L: $\quad$ length of first metatarsomere

HT4L: combined length of second to fourth metatarsomere.

3. Description of new species and additional records of Myrmecopora SAULCY

Myrmecopora (s. str.) ciliciana sp. n.

Figs. 1-8, Map 1

Holotype o [with worker of Messor cf. caducus attached to the same pin]: TR - Mersin, ca. $30 \mathrm{~km}$ NNW Tarsus, $580 \mathrm{~m}$, No. 8, $37^{\circ} 10^{\circ} 00 \mathrm{~N}, 34^{\circ} 45^{\circ} 40 \mathrm{E}$, fallow with decid. trees, 26.12.2000, V. Assing / Holotypus ơ Myrmecopora ciliciana sp. n. det. V. Assing 2001 (cAss).

Paratypes: $4 \sigma^{\star}, 6 \circ$ 우 [one dissected + with mature egg in ovaries], same data as holotype, leg. Assing, Wunderle (cAss, cWun).

\section{Description}

Measurements (in mm) and ratios (range; $\mathrm{n}=5$ ): $\mathrm{AL}: 1.35-1.38\left(\sigma^{*}\right), 1.13-1.21$ (9); HL: $0.41-0.44$; HW: $0.48-0.57$; PL: $0.42-0.48$; PW: $0.50-0.57$; EL: $0.36-0.42$; HTiL: 0.60 - 0.68; HTaL: $0.56-0.62$; HT1L: 0.21 - 0.24; HT4L: $0.23-0.24$; TL: $3.2-3.8$; HW/HL: 1.14 - 1.27; PW/HW: 1.00 - 1.07; PW/PL: 1.15 - 1.19; EL/PL: 0.81 - 0.90; HTaL/HTiL: 0.91 - 0.93; HT1L/HT4L: $0.91-1.00$.

In general appearance similar to $M$. pygmaea (SACHSE). Colour of body dark brown, with the elytra, the posterior margins of the abdominal terga, and sometimes also the anterior parts of the anterior abdominal terga light brown to reddish brown; legs testaceous; antennae ferrugineous.

Head distinctly transverse (see ratio HW/HL), with fine and sparse puncturation; in $\sigma^{*}$ dorsally with pronounced posterior impression, in $q$ without such impression. Anten- 
nae moderately long (shorter than in $M$. pygmaed) and with sexual dimorphism: in $0^{*}$ longer (see measurements), preapical antennomeres approximately as wide as long; in of shorter and with slightly transverse preapical antennomeres (Figs. 7, 8).

Pronotum distinctly transverse (see ratio PW/PL) and with pronounced sexual dimorphism: in o with broad (approximately half the width of pronotum) and deep median impression extending over whole length of pronotum and with dense and granulose puncturation; in $q$ with narrow and shallow median impression and with finer puncturation.

Elytra at suture slightly shorter than pronotum (see ratio EL/PL) and with fine and rather dense puncturation.

Legs long and slender; metatarsi almost as long as metatibiae (see ratio HTaL/HTiL); first metatarsomere approximately as long as the combined length of the three following tarsomeres (see ratio HT1L/HT4L).

Abdomen with fine and relatively dense puncturation.

o: sternum VIII posteriorly weakly convex and with long marginal setae (Fig. 4); aedeagus with ventral process of median lobe abruptly narrowed in ventral view (Figs. 1,2). o : sternum VIII posteriorly \pm concave and with long thin marginal setae (Figs. 5, 6); spermatheca as in Fig. 3.
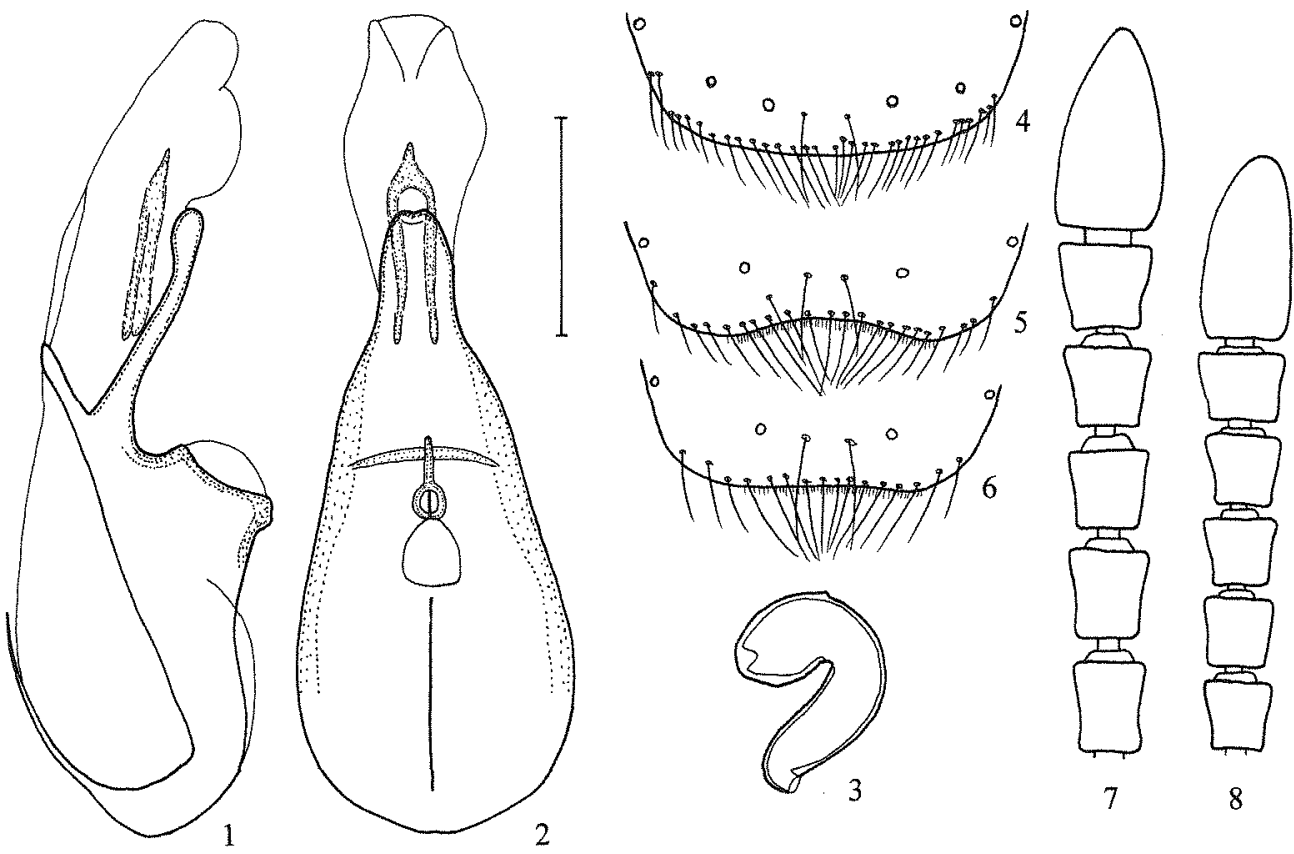

Figs. 1-8: Myrmecopora ciliciana sp. n.: median lobe of aedeagus in lateral and in ventral view $(1,2)$; spermatheca (3); posterior margin of of sternum VIII (4); posterior margin of $q$ sternum VIII of two $q 9(5,6)$; apical half of antenna of $\sigma^{*}(7)$ and $\%(8)$. Scale: $0.2 \mathrm{~mm}$. 
Derivatio nominis: The name (adj.) is derived from Cilicia, the ancient name of the region where the species was discovered.

\section{Comparative notes}

From the externally similar $M$. pygmaea from the Balkans, M. ciliciana is distinguished especially by the shorter antennae with less elongate antennomeres, the more pronounced impressions on the $\delta$ head and pronotum, and by the shape of the ventral process of the aedeagus, which is weakly and smoothly tapering apically in $M$. pygmaea. From $M$. wunderlei ASSING, which, too, occurs in southern Anatolia, the new species is readily separated by the much shorter legs and antennae (see figures in ASSING, 1997a), by the more transverse pronotum, and by the morphology of the aedeagus. In $M$. publicana SAULCY, whose distribution ranges from Israel to southern Anatolia (Antakya) and in which the aedeagus and antennae are of similar morphology, the pronotum is less transverse, the head is on average more weakly transverse, the impression on the ot head is less pronounced and more distant from the posterior margin of the head, the impression on the $\sigma^{*}$ pronotum is usually narrower, shorter (though sometimes equally deep), and finely punctate, the aedeagus is smaller, the posterior margin of the o sternum VIII is not concave, and the capsule of the spermatheca is of different shape (see figures in ASSING, 1997a).

In order to accommodate the new species, the key in ASSING (1997a) is modified as follows:

5. Small species (TL: $2.5-3.2$ ). Antennae shorter (AL: $0.95-1.16 \mathrm{~mm}$ ); antennomeres IV - IX subquadrate $(\%)$ to weakly oblong $\left(\sigma^{*}\right)$, and X subquadrate or slightly transverse. Legs, especially tarsi, relatively short (HTaL: $0.50-0.61 \mathrm{~mm}$ ). Eyes larger, approximately as long as postgenae in dorsal view. Dotsal surface of head and pronotum distinctly convex; the latter strongly transterse (PW) PL: 1.22 - 1.35). Sexual dimorphism very indistinct: of with very faint, almost obsolete dorsal impression on head, pronotum with roughly triangular shallow median impression near posterior margin and very fine and narrow, almost obsolete sulcus along median line; $\&$ pronotum with shallow triangular impression, occasionally with short and sulcate anterior extension. of: ventral process of median lobe relatively wide and short in ventral view (Fig. 4a in AssING, 1997a). 7 : spermatheca similar to that in M. pygmaea (Fig. 4b in AssiNG, 1997a). Recorded from western Anatolia and the southeast of Bulgaria. M. (s. str.) convexula Assing

Dorsal surface of head and pronotum less convex, sometimes even flattened. Pronotum less strongly transverse. Antennae longer (AL: $>1.10 \mathrm{~mm}$ ) and in most species with more slender antennomeres. Eyes relatively smaller, usually distinctly shorter than postgenae in dorsal view. Sexual dimorphism usually more pronounced: of mostly with \pm deep dorsal impression on head, pronotum generally with broader longitudinal impression; $q$ usually with more extensive impression in posterior half of pronotum.

$5 \mathrm{a}$

5a. Antennae relatively shorter and less slender, antennomere IV in or less than $1.5 \mathrm{x}$ as long as wide and in 9 only indistinctly oblong, antennomere $X$ approximately as wide as long ( $\sigma^{7}$ ) or weakly transverșe ( $\%$ ) (Figs. 7, 8). Pronotum with pronounced sexual dimorphism, in $\sigma^{*}$ with broad (ca. half the width of pronotum) and deep median impression extending over whole length of pronotum and with rather dense and distinctly granulose puncturation. o: aedeagus with ventral process of median lobe in ventral view abruptly tapering (Figs. 1, 2), 9 : spermatheca as in Fig. 3. Central southern Anatolia (Mersin).

M. (s. str.) ciliciana sp. $\mathrm{n}$.

Antennae relatively longer and more slender, antennomere IV at least $1.5 \mathrm{x}$ as long as wide and antennomere X ustally distinctly oblong. Pronotum in of with weaker or differently shaped impression and at most with weakly granulose puncturation. $\delta$ : aedeagus of different morphology. Absent from Turkey, except for one species from southwestern Anatolia. 


\section{Distribution and bionomics}

The types were found some $30 \mathrm{~km}$ northwest of Tarsus in the east of the province Mersin, central southern Anatolia (Map 1). They were collected in two ant nests under stones in a fallow with some deciduous trees and surrounded by agricultural land (elevation: $580 \mathrm{~m}$ ). The host ant is apparently the same species (Messor cf. caducus (VICTOR)) as that of Myrmecopora pygmaea and M. wunderlei (see Assing $(1997 \mathrm{a}, 1999)$ and records of $M$. wunderlei below). One dissected female had a mature egg in the ovaries, so reproduction apparently takes place in winter.

\section{Myrmecopora (s. str.) wunderlei Assing Map 1}

Material examined: Turkey (southern Anatolia): 10,1 , Antalya env., road to Saklikent, $500 \mathrm{~m}$, under stones, 10.V.2000, leg. Meybohm (cAss); 1 o , Mersin, road from Anamur to Ermenek, km 21, 350m, 17.V.2000, leg. Meybohm \& Brachat (cAss); 1 ㅇ, Mersin, N Anamur, $36^{\circ} 12 \mathrm{~N}, 32^{\circ} 53 \mathrm{E}, 800 \mathrm{~m}, 17 . \mathrm{V} .2000$, leg. Meybohm (cAss); $30^{\circ}$ oे $^{\circ}, 1$ 우 (partly teneral), same data, but 19.V.2000, with Messor caducus (CAss); $100^{\star *} 0^{*}, 12$ ㅇ 9 , Mersin, ca. $15 \mathrm{~km}$ W Silifke, $36^{\circ} 22^{\prime} 43 \mathrm{~N}, 33^{\circ} 49^{\prime} 34 \mathrm{E}, 475 \mathrm{~m}$, roadside, with Messor caducus, 27.XII.2000, leg. Assing, Wunderle (cAss, cWun).

M. wunderlei is here for the first time recorded after its description. Its known area of distribution now ranges from the area west of Antalya to Silifke (Mersin) in southern Anatolia (Map 1). Two specimens collected in May were teneral suggesting that larval development takes place in winter and early spring.

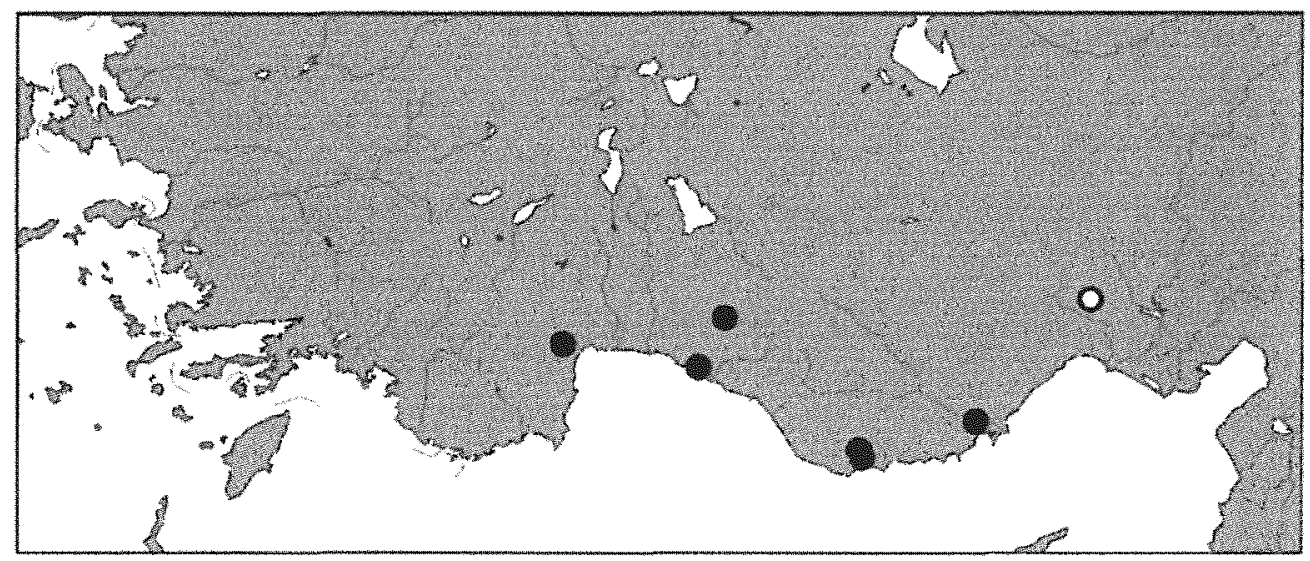

Map 1: Distribution of Myrmecopora wunderlei Assing (filled circles) and M. ciliciana sp. n. (open circle) in southern Anatolia (Turkey). 


\section{Mytmecopora (Iliusa) fugax (ERICHSON)}

Material examined: Spain: 1 , , E-Mallorca, Son Carrio, garden refuse, IV.2000, leg. Feldmann (cFel). Israel: $20^{*} o^{*}, 3$ क 9 , Golan, Mahjar, 200m, 27.IV.1982, leg. Besuchet \& Löbl (MHNG, cAss).

\section{Myrmecopora (Paraxenusa) laesa (ERICHSON)}

Material examined: Malta: $10^{\circ}, 4 \% \circ$, St. Thomas Bay, 12.V.1990, leg. Mifsud (cMif, cAss); $50^{\star} o^{7}+3 q q$, Dragonara, 10.IX.1989, leg. Mifsud (cMif, cAss); $1 q$, Gnejna, 9.V.1990, leg. Mifsud (cMif); 10 , 1 \%, Gozo, Famla, 8.V.1990, leg. Mifsud (cMif, cAss).

\section{Myrmecopora (Xenusa) uvida (ERICHSON)}

Material examined: Russian Federation: $13 \sigma^{\circ} \sigma^{*}, 11 \% \circ$, Krasnodar Territory, near Taman, seashore, 13.V.1995, leg. Solodovnikov (cSol, cAss).

\section{Myrmecopora (Xenusa) bernhaueri KocH}

Material examined: Egypt: $120^{\star} \sigma^{*}, 10$ 우, Hurdagha (= Al Ghardagah), coast of Red Sea, in seaweed, 1.-7.XII.1991, leg. Uhlig (MNHUB, cAss); $30^{\star} \sigma^{*}, 5 \%$ \% , Sinai, Dahab, beach, III.1989, leg. Balke (MNHUB, cAss).

\section{Acknowledgements}

I am grateful to all the colleagues indicated in the material section for the loan of material. In addition, I would like to extend my thanks to VOLKER BRACHAT, Geretsried, and HEINRICH MEYBOHM, Stelle, for the generous gift of the Myrmecopora collected during their joint excursion to Antalya and Mersin as well as to PAUL WUNDERLE, Mönchengladbach, for his company during the Christmas field trip to central southern Anatolia in December 2000.

\section{References}

ASSING, V. 1997a: A revision of the Western Palaearctic species of Myrmecopora SAULCY, 1864, sensu lato and Eccoptoglossa LuZE, 1904 (Coleoptera, Staphylinidae, Aleocharinae, Falagtiini). - Ent. Beitr. Berlin 47: 69151.

Assing, V. 1997b: A revision of the Eastern Palaearctic species of Myrmecopora SAULCY, 1864 with notes on some species from the Oriental region (Coleoptera: Staphylinidae, Aleocharinae, Falagriini). - Beitr. Ent. Berlin 47: 337-352.

ASSING, V. 1999: A revision of the Palaearctic species of Myrmeropora SAULCY, 1864 and Ecroptoglossa LuZE, 1904 (Coleoptera: Staphylinidae, Aleocharinae, Falagriini). Supplement I. - Entomol. Z. 109: 499-504.

Author's address:

VOLKER ASSING

Gabelsbergetstr. 2

D-30163 Hannover

Germany

e-mail: vassing.hann@t-online.de 